\title{
Interrelation of Environmental Communications through Radio Broadcast Resources (Research on Love of House Yard Movement in Sub-Province Sangihe, Indonesia)
}

\author{
Reiner R. Onsu ${ }^{1}$, Agus Suman ${ }^{2}$, Soemarno $^{3}$, Zetly Tamod ${ }^{4}$
}

\begin{abstract}
This research was conducted to analyze the process of interrelation between environmental communication and environmental management policy through radio broadcast resources in the suburb area and changes in environmental sociology. The necessary data include primary data and secondary data obtained by using: documentation and literature study, in-depth interview, observation which is observation of phenomena that are directly related to the observed target and just limit the issues in question and recording. Data analysis was conducted descriptively to describe systematic, factual and accurate, facts and properties of study area in accordance with the problems.

The results showed that movement program and radiobroadcast organizer do not move the interrelation society related to new culture in environment such as lifestyles, a balance living pattern according to the capacity of the social environment. Interrelation society with movement program, both individuals and groups, are depends on their interest and image to policymakers. It is because of policy program was universally impressed, so less attention for the interest of structural-functional continuously.
\end{abstract}

Keyword: interrelation, environment communication, movement, archipelago of Sangihe.

\section{Introduction}

The main problem faced in environmental management are, mainstreaming application of Global environment issue to national development pattern and development of area, equality of environmental regulation, and low awareness of society in conservancy of environment, resulting degradation of environment quality as prop of life, (Robert C Palmer, in Carolyn Abbot, 2010) explaining 'related environment', that the entry of information create 'awareness of environment' through important regulation instrument, to limit environment endangering activity.

Problems found in frontier region, including in region frontier of Indonesia and Philippines, especially in Tahuna sub-province archipelago of Sangihe,which is integral part of north Sulawesi province, with Tahuna. One of the efforts in maintaining the quality of environment is to give education, resuscitation to society about environment through radio broadcast. Changara(2006).

This matter is very clearly arranged in law Number 32 year 2002 about broadcasting and also in law number 32 year2009 about management and environmental Protections.

In context of environmental management, role of media can be optimal by promoting caring values to environment, monitoring and controlling to policy, and primal voice policy demands related to management of environment. Ardianto, Elvinaro (2004)

Research of Kurniawan (2006) about how environmental news which done by mass media specially newspaper and it's implication to policy of environmental management in sub-province of Bangka.

Result of its research show news intensity, Post Bangka most intensive carried environmental issues and problems compared to Babel Post and People Post.This is seen from high news frequency. The implication on social control aspects are opened for all criticism, inputs and policy demand. At policy aspect showed the improvement existence of environmental planning management in sub-province of Bangka with the increasing participation of society .Inmedia aspect, progressively opening the role of media to be active in controlling and linking among stakeholders in environmental managements. As recommendation, media suggested to be optimal of its role through the make-up of its journalist capacities and performance to control policy and also become active in communications forum between stakeholders.Government is expected to be more responsive, improving Human resource and integrity, consistent in upholding the order, transparent, and all that important is to grow and at the same time open room to society to be active to participate in management of environment.

In general, the question of research is whether is it effective to use of radio broadcast resource in continuous development of environment in region frontier of Indonesia - Philippine?So the formula issue of this research that is, how is the interrelation between environmental communications with the policy of environmental management in frontier region? 
This research aims to describe and analyze the process of adaptation between environmental communications through radio broadcast resource with policy of environmental management in frontier region.

The result of this research is expected can add knowledge and give contribution to the growth of environmental communications science and change of environmental sociology of society in frontier region in exploiting radio broadcast resource.

\section{METHODOLOGY}

\subsection{Research Location andTime Execution}

The research was conducted in region frontier of Indonesia and Philippine. Focus intake of sample in Tahuna city, the capital of regency archipelago of Sangihe. Northern part of this area is Maroreand Abutingwith Balut and Saranganiisland, regional of republic of the Philippines (Southern Mindanao) and also reside in ocean lip of Pacific with time execution of December 2011 - July 2012.

\subsection{Technique of Data Collection}

Researcher obtained data and reference from research region through documentation analysis and bibliography study (library research) that is reading various literatures like books, journals andother reading source through media of internet.Researcher got primary data from in - depth interview with informant related to aim of the research.Researcher done perception and observation of events and phenomenon able to perceive directly in research location to strengthen and agree obtained data from interview with all informant to find result related to the topic.At recording step, related information or data which stem from all informant recorded by using recording tools, such as radio tape, camera, and video camera.Recording is to clarify the description concerning various situation and behavior of subject of the research.

\subsection{Research Informant}

This research context, informant is those who following movement program through radio broadcast as direct effect, and those who did not follow radio broadcast, as indirect effect, through environmental communications of consanquinity culture, with classification: age, status in family, experience, education, job, and experience.Informant who becoming the source of information in this research shall be as follows: (table 1)

Table 1.Informant and his/her qualification

\begin{tabular}{|c|l|l|}
\hline No & \multicolumn{1}{|c|}{ Name } & \multicolumn{1}{c|}{ Official statements } \\
\hline 1 & $1^{\text {st }}$ informant & Last education: $1^{\text {st }}$ Degree, field executor of radio broadcast program \\
\hline 2 & $2^{\text {nd }}$ informant & Last education: $1^{\text {st }}$ Degree, decision maker of Gentaharu program policy \\
\hline 3 & $3^{\text {rd }}$ informant & Last education: 1st Degree, decision maker of Gentaharu program policy \\
\hline 4 & $4^{\text {th }}$ informant & Last education: 1st Degree, field executor of Gentaharu program \\
\hline 5 & $5^{\text {th }}$ informant & $\begin{array}{l}\text { Last education: Jr. High school, often listening to radio broadcast and didn't execute } \\
\text { Gentaharu program }\end{array}$ \\
\hline 6 & $6^{\text {th }}$ informant & $\begin{array}{l}\text { Last education: Sr. High school, often listening to radio broadcast and didn't execute } \\
\text { Gentaharu program }\end{array}$ \\
\hline 7 & $7^{\text {th }}$ informant & $\begin{array}{l}\text { Last education: Elementary, not listening to radio broadcast but execute Gentaharu } \\
\text { program }\end{array}$ \\
\hline 8 & $8^{\text {th }}$ informant & Public Figure \\
\hline
\end{tabular}

For the requirement of validity, same question was also raised to other informant to check how far equality or difference between information discovered from various informants.If statements of the informants identified are the same, hence this matter is considered to be commons knowledge (Udehn 2011).

Obtained information about radio broadcast resource: covering the amount of radio broadcast, overseas and domestic which is reachable, transmitter reach, quality of acceptance, quality of environmental broadcast content, environmental broadcast items, environmental broadcast time, target of radio broadcast.

Management of environmental movement program which cover planning on love of house yard movement, in relation with the environmental quality and impact, is also revealed from some informant related to condition of frontier region about social environment, education of environment and development of region.

\subsection{Descriptive Analysis of Data}

systematic description, factual, accurate of results of interview concerning the facts and nature according to the problems with detailed picture about social situation of research region, formulated and explained all obtained fact and information in the form of data, then developed furthermore.Detailed descriptions is conducted to explain situation, event, people, interaction, and behavior, statements of experience, attitude, confidence, and thought, and also passages of document content as written in transcript interview or field note. 


\subsection{MainBroadcast Items}

\section{Result And Discussion}

Information broadcast items and non-formal education which is recorded in interview with informant concerning rural broadcast, culture and environment shall be as follows:

"Broadcasting on farming, plantation, fishery / oceanic, middle and small industrial, housing, health and etc., supporting motion fluency and society effort," exchanging information" between society in rural area, interaction ( having conversations) on items matching with area characteristic" ${ }^{5}$

"environmental broadcast program is one of the our event which is mostly followed by society contain invitation to love environments, in the form of information broadcast which is dynamic, creative, attractive and persuasive, and also make society as broadcast subject in the form of spot"

"Improving, understanding and society awareness on the importance of repairing, developing and preserving environment.Inculcating cultural value "Shame" of matter that able to destroy environment. Inculcating behavior "Healthy life" by balancing environment and nature, and also preserve mutual assistance culture for the saving of environment"

"one of the event followed by society is regarding the continuation and resourcing all culture and art by which is potential in developing unity of nation with event items about kinds of area culture and art with combinations items of artistic element, voice and music, artistic say, mores and also tradition, interactive dialogued / discussion in appreciation form, by figuring culture experts/musicians/artist ${ }^{8}$

"Converting information" and or form of interactive with a purpose to the development of society, becoming part of reason as a development and improvement process of ability to act collectively ( Phillips and Pittman, 2009), society involvement needed by radio broadcasting organizers to accurately figure out and also understand the real social needs and conditions. These findings agree to Maslow's which adopted in broadcasting strategy in relation with listeners wants and needs. (Dominick, 2001).

\subsection{Policy Movement on Love of House Yard Program.}

Lawn in this region needs a better settlement, so that it will affect to the prosperity of society, besides social relation function, culture and economic function.

Love of house yard movement acted by national program implementation then become area program. Love of house yard movement is triggered since 2007 cooperation between society and government. As an evidence that the dependence of high importing of food supplyare enough as an effect of low agriculture productivity. In interview with informant that:

The aim of policy movement on love of house yard is how we can exploit existing farm either in around our house and also house in range, through the availability of food in household level.(informant ${ }^{9}$ )

Society action on exploiting farm lawn is a social movement, as a collective effort to pursue a common interest, or reach the target through collective action. (Giddens, in Suharko, 2006)

Society participation in governmental program can minimize dependence, at the same time the development of food resilience in household storey are keep on increasing in quality and also nutrients.

Participation according to Uphoff, Kohen, and Goldsmith ( 1979), descriptive term which is an involvement of some people with a significant amount in so many action or situation that able to improve prosperity of their life. The target of this policy program is:

"society, either through groups and also individual, given high priority for housewives, as taker of decision in preparing menu every day so they should be given skills so that they do not have to buy from market but can be created through exploiting of lawn, started from home - food endurance - increasing of nutrients depressing household expense - improving earnings of family " (informant 3 )

According to Mitchel (1982), motivations deputize process of psychological, causing, the happening of persistence on voluntary activity which instructed toward specific-purpose. An effort in facilitating society in managing local resources, collective actions and networking is a process to make the society can be proportional and be a main doer.It's implication, that a family knows about farming, poultry or fishery, as expressed by informant:

"yaabolehjo, daripada tempo nikintalndaadatanamanapa-apa for jatongka-tongka di dapur, jadilumayanjo, sekaligusikorame, napadorangbirman-birman so batanam, dengsatu lei, dengar di radio dang, daripadamopigibelidipasarongkos lei" (informant 6 and 7)

(not bad, compared to the condition of previous house yard which not planted with crop for the kitchen needs, see neighbors have planted their yard and also listening to radio broadcast, than going to the market have to release expense)

Thereby requirement of food resilience in household level can be overcome at the same time lessen depended food supply from outside area which induce the prosperity of society of Sangihe. 


\subsection{Interrelation on Love of House Yard with Radio Broadcasting.}

As the next action of area movement program on love of house yard:

"Steps taken in doing every program are adapted by local wisdom and situation". (Informant 2)

Many agreed that participation require to be done in implementation of movement program on love of house yard. Therefore in the plan and execution of program have to comprehend real correctly concepts to support the presence of society participation sub-province archipelago of Sangihe. According to Pretty and Guitj, in B Mikkelson (2001) explaining practical implication of this approach that, development of participation approach have to start with people who really knows about their own life system. This approach has to assess and develop knowledge and skills so that they can develop themselves. Variety social cultural of society which not formed briefly, local wisdom comprehended as local idea, full of wisdom, having the character of wisdom, valuable of goodness planted and a conceptual idea living in sub-province society archipelago of Sangihe. In field interview we discovered that.

"Guidance demonstration in each countryside to support the area program with socialization through mass media, invite society citizen of Sangihe to start to plant, suggesting that society of Sangihe have to take action with this program in relation with a movement of touching earth and land with a meaning of exploiting a length of land" ( informant 4,5,6,7)

Articulation of interrelation between radio broadcast and policy with local knowledge of society , clearly can be seen at table 2 .

Table 2.Interrelation Program onLove ofHouse Yard Movementand Radio Broadcasting.

\begin{tabular}{|c|c|c|c|}
\hline \multirow[t]{2}{*}{ No } & \multirow[t]{2}{*}{ Approach } & \multicolumn{2}{|c|}{ Implication } \\
\hline & & $\begin{array}{l}\text { Love house yard } \\
\text { movement program }\end{array}$ & Radio Broadcast \\
\hline \multirow[t]{3}{*}{$\begin{array}{l}\text { 101.Social } \\
\text { Communication }\end{array}$} & $\begin{array}{l}\text { - Understand the concepts of life } \\
\text { and society habits }\end{array}$ & $\sqrt{1}$ & $\sqrt{ }$ \\
\hline & - $\quad$ Understanding society life systems & $\sqrt{ }$ & $\sqrt{ }$ \\
\hline & $\begin{array}{l}\text { - Understanding local knowledge } \\
\text { and skills, attitude pattern }\end{array}$ & $\sqrt{ }$ & $\sqrt{ }$ \\
\hline \multirow[t]{2}{*}{ 02. Socialization } & $\begin{array}{l}\text { Inviting and instructing society } \\
\text { through the approach of } \\
\text { environmental communications by } \\
\text { using radio broadcast mass media. }\end{array}$ & $\sqrt{1}$ & $\sqrt{1}$ \\
\hline & $\begin{array}{lll}\text { - } & \begin{array}{l}\text { Building perceptions and } \\
\text { participations }\end{array} \\
\end{array}$ & $\sqrt{ }$ & $\sqrt{ }$ \\
\hline \multirow{2}{*}{$\begin{array}{l}\text { 03.Guidance/Supplying } \\
\text { media }\end{array}$} & - $\quad$ Making demonstration in village & $\sqrt{ }$ & $\sqrt{ }$ \\
\hline & - $\quad$ Developing knowledge and skills & $\sqrt{ }$ & $\sqrt{ }$ \\
\hline 04.Assessment/Evaluation & $\begin{array}{l}\text { - } \begin{array}{l}\text { Competitions and emulation } \\
\text { between villages }\end{array}\end{array}$ & $\sqrt{ }$ & $\sqrt{ }$ \\
\hline
\end{tabular}

Source: research result data (2012)

Tables 2 above explaining how closely interrelation between program on love of house yard movement and radio broadcast with local wisdom exist in society. Such Interrelation is an articulation which base on habits that goes on in society,JhonMicklethwait (2007) to face globalization era which continue to run over this world society, we need to study wisdom comprehensively. At least,interrelation policy level, and in relation with radio broadcast application with life concepts, local knowledge skills and systems of sub-province society archipelago of Sangihe.

\subsection{Tendency of Increasing of Formal Education and Society Knowledge to Accept Informationand Innovations from the Government.}

Critical reflection of frontier society in taking decisions to face the reality of his/her environmental phenomenon of life relate to method and norms related to environment that is knowledge, attitude, individual behavior, and behavior of group. Cultural and social relation pattern binding this region integrated through technology and existence of social organization and also influenced by amount and behavior of society and so do education level.

This relation pattern found at cultural adaptation of society of Sangihe to their environments. Cultural Adaptation phenomenon related with relevant conception change and social reality, that the society of this region has a tendency of changes can be seen at pattern of natural resources exploitation, such as farming, mangrove, scarce animal, protected forest, fishery, agriculture and plantation.Pursuant to understanding of change conception, Et al Atkinsson (in Nurhidijah, 2003), express that changes is an activity or process making something or someone differ from previous situation and a process causing change of individual behavior pattern. 
Social dimension relate to education context, economic and health, among others the source of information related to amount and quality, discovered in perception in this region is influenced by informal education level which have estuary in problem of and health of nutrients especially in isles. Joe Park: "education the art of processing of imparting or acquiringknowledge and habit through instructional as study".Pressure congeniality of education is at the activity of instruction, and constructed personality of cognate aspect and habit.Although, non-formal education of society, is, in fact formed pursuant to endowed knowledge of generation to generation.So that, if seen from its relevance in context of change, hence clear that changes will always accompany those non formal educations, because it is always confronted in accomplishment of life needs which increasing day by day whether in quantity and also in its quality.

Society behaviors to environment caused by basic factors, supporter, perception and impeller, and also physical and social factor of the environment. Among those factors, the important elementary factor is view of life, mores, trust and habit of society.Supporting factors covered education, work, cultural and social strata, while its impeller factor is touch of mass media, (electronic and also written), counseling, figures of religion and also figures of society. How far the absorbtion of information by someone depends on psychological dimension and perception to environment, henceforth will be reflected to his/her behavioral (Su Ritohardoyo, 2006).Fact about the lack of education and change of individual behavior or institution, if confronted with government policy put on is society, hence there are two important impacts to behavior of society; supporting and impeding policy. (Table 3)

Table 3. Supporting and Impeding Factor of Environmental Communications Interrelation with Movement Program

\begin{tabular}{|c|c|c|c|}
\hline \multicolumn{2}{|c|}{ Environmental Behavior } & Supporting & Impeding \\
\hline \multirow[t]{2}{*}{ Basic } & Society habit & Inheritance of previous & \multirow{2}{*}{$\begin{array}{l}\text { Technology, communication, } \\
\text { consumption pattern, trend, } \\
\text { perception, tradition, mental }\end{array}$} \\
\hline & View of life, mores, believes & generation & \\
\hline \multirow[t]{3}{*}{ Supporting } & Occupation & & \multirow{3}{*}{$\begin{array}{l}\text { Way of thinking } \\
\text { Activity/routine } \\
\text { Formal and non-formal } \\
\text { education }\end{array}$} \\
\hline & Education & & \\
\hline & Social levels and culture & & \\
\hline \multirow[t]{2}{*}{ Impeller } & Communication & Internal kinship & Internal kinship \\
\hline & Mass media & National broadcasting & International broadcasting \\
\hline
\end{tabular}

Source: Research result data (2012)

Behavior of society related to environment, when parallel with policy of governmental program, in the reality have two sides which is following each other, that is supporting and impeding; both aimed to adaptation of environmental communications interrelation. Result of interview can be summarized as follows:

"Policy of government in program level basically is in mutual accord with lots of local knowledge which expand in society, as life view, mores, and habit of society". (Informants 1,3 and 7).

There is part of love of house yard program which disagree with local knowledge which become tradition in local society, for example habit which is viewed in society:

"lawn management is a new matter but not their habit; habit to collect vegetable in forest and around river lessening creativity and enthusiasm to manage and exploit lawn; culture of society during the time that planting annual crop ( coconut, nutmeg, clove, for example) and condition of fisherman society; habit of many people who prefer to plant decorative crop in house yard; some complicated and difficult assumed phase start from preparation of farm as planting media, treatment, and others; economic level of sub-sistence result many people feel or depended to their environment; it is not allowed to plant lemon because it's thorny and can make us difficult to get "couple"; have to see time planted; moon position; plant position, right or left; habit to farm conventionally" ( informant 8)

Life value unite become one in the form of trust, cultural and mores, for example "depilatory and combustion or changing the functions of land and forest can cause erosion and landslide, loss of fertility of land/ground, as according to condition of topography". According to ecology conception is the loss of humus coat and of microorganism, important elements of land/ground, and ability of land/ground to do waste decomposition, this land/ground degradation is also caused by the usage of chemical substance (pesticide).

" also discovered house yards with no fence, if fenced, there's still always an open part or has a door which is easy to be opened to still give freedom to common people and animal to enter the lawn; there are also lawns occupied by more than one family" ( informant 8)

In everyday life of the society, most of the time was spend in garden and look for fish in the sea, when returning home usually have fatigue.

Knowledge of society about the meaning of health and nutrients, requirement of nutritious food, response of thrift of economics, and esthetics value; very beneficial in accomplishment of family needs, familiarity, life believe in, kinship.

Communications adaptation positively inter-related with social solidarity value related to perception, spirit pushed by the existence of internal and external factor related to information through overseas and also 
domestic radio broadcast; helpful effort pushed by feeling / desire of re-compensation because have accepted aid related to good model of the leaders; law obedient culture.Absorbtion of global culture bear the existence of new habit as impact of progress of communications technology if compared to old habits (local wisdom) resulting friction which is tendentious for example, prefer to go shopping to market, with double function; more practical and trend, affecting a high expense economics.

Rise of production can be felt by small part of society following it continuously because they can feel the existence of additional earnings in fulfilling family needs, but they did not followed all movement programs, adjust to their own local wisdom, such as, unaccustomed in using manure, dividing time, and also already accustomed relying on cheapness of nature. These are facts showing adaptation process of inter-relation environmental communications.

\section{Conclusion}

\section{Suggestion And Conclusion}

1) Inter-relation of love of house yard movement program and radio broadcast not yet walked according to target. Some approach of technology in reality impinge with social communications which is functionally become important part of expanding culture in sub-province society of Sangiheso that not yet fully succeeded to move society participation.

2) Love house yard movement program is less in paying attention on most touching matter of functional structural importance on an ongoing basis, but program performance (product) has succeed and well accepted by society. Movement program not yet earned to build participation on an ongoing basis.

\section{Suggestion}

policy shall maintain the access of medium and supporting medium of environmental communications through approach of technology, approach of social environment in functional structural and pay attention to the balance as according to supporting energy of social environment,the most touching so that do not bother the balance of relation even as possible keep the balance of relation that could able build functional participation and perception which bear independence in order not to impress in society "lost program, lost action".

\section{Bibliography}

[1]. Ardianto, Elvinaro (2004). Komunikasimassa :SuatuPengantar. Baandung: SimbiosaRakatama Media

[2]. Ardianto, ElvinarodanLukiatiKomalaErdinaya, 2007.Komunikasi Massa SuatuPengantar. Bandung :SimbiosaRaktama Media.

[3]. Berg, B L. 2001. Qualitative Research Method For Social Science. USA: Alin and Bacon.

[4]. BrithaMikkelsen 2003. Metode Penelitian Partisipatorisdan Upaya-upaya Pemberdayaan : sebuahbukupeganganbagiparapraktisilapangan. Jakarta :YayasanObor Indonesia.

[5]. Cangara ,Hafield. (2006). Pengantar Ilmu Komunikasi. Cetakan pertama. Jakarta : Rajawali Pers.

[6]. Carolyn Abbot - Enforcing Pollution Control Regulation (Oxford, UK and Portland, OR, Hart Publishing, 2010) (257pp; ISBN: 978-1-84113-925-8, Hardback, £40.00) Review by Robert C PalmerTPF.

[7]. Conyers, Diana. 1991. Perencanaan Sosial di Duniaketiga. Yogyakarta: UGM Press.

[8]. DedyMulyana, 2003. Ilmu Komunikasi, Suatu Pengantar. PT. RemajaRosdakarya : Bandung

[9]. Effendy, OnongUchjana. 1989. KamusKomunikasi. Bandung :MandarMaju.

[10]. Giddens, suharko, 2006 dalamBelajarl 2011 SOCIAL CHANGE and SOCIAL MOVEMENT http : //jeffylouis.blogspot.com/2011/04/social-change-and-social-movement.html Gordon, W, 2011. Behavioural Economics and Qualitative Research - A Marriage Made In Heaven? International Journal of Market Research Vol. 53 Issue 2

[11]. Gunarsa, S.D. 1989. Psikologi Perkembangan: Anakdan Remaja. Jakarta: BPK. Gunung Mulia.

[12]. John Micklethwait, Adrian Wooldridge 2007.Masa Depan Sempurna, Tantangandan Janji Globalisasi (diterjemahkanolehSamsudinBerlian). Jakarta: YayasanObor Indonesia

[13]. Manzilati, A. 2008. Tata KelolaKelembagaan (Institutional Arrangement) Kotrak Usaha Tani DalamKerangkaPersoalanKeagenan (Principle-Agen Problem) Dan Implikasinya TerhadapKeberlanjutan Usaha Tani. Disertasi, Program DoktorIlmu Ekonom Program Pascasarjana Fakultas EkonomidanBisnis Universitas Brawijaya.Tidak Dipublikasikan

[14]. Masduki. 2004. Jurnalistik Radio. Yogyayakarta: LKIS

[15]. Mitchell, TR. 1982. Motivation: New Directions for Theory, Research, and Practice. The Academy of Management Review, 7(1): 80-88. Online at <http://www.jstor.org/stable/257251> [accessed 29 July 2011]

[16]. Musa Angelo 2011 Karakteristik radio http: //musa 666. wordpress. com/ 2011/10/04/karakteristik-radio-siaran

[17]. Nurhidiyah, R.E. 2003. Keperawatandan Perubahan. Makalah Tugas Akhir PadaF akultas Kedokteran Program StudiIlmuKeperawatan.Universitas

[18]. Peter K. Pringle, Michael F. Starr and William E. McCavitt 1991, Electronic Media Management

[19]. Phillips, Rhonda and Robert Pittman. 2009. An Introduction to Community Development. Out Ledge.London and New York.

[20]. Sri Handayani 2012PenerapanMetodePenelitian Participatory Research ApraisalDalam Penelitian Permu kiman Vernakular (Permu kiman Kampung Kota)

[21]. Su Ritohardoyo, 2006. Bahan Ajar EkologiManusia. Program StudiIlmuLingkungan, Sekolah Pascasarjana, UGM, Yogyakarta

[22]. UndangundangNomor 32 Tahun 2009 tentangPengelolaandanPerlindunganLingkungan Hidup.

[23]. Undang-undangNomor 32 Tahun 2002 TentangPenyiaran

[24]. Uphoff, Kohen, dan Goldsmith 1979, KonsepPartisipasiMasyarakat http: // www. scribd. com/doc /55927790 / di unduhNopember 2012.

[25]. Vainderstoep, S W dan D J. Deirdre 2009. Research Method Of Every Day Life: Blending Qualitative And Quantitative Approach. Sanfransisco: John Willey And Sons.

[26]. Yoseph Dominick. 2001. Broadcasting, Cable, The Internet and Beyond, An Introduction to The Modern Electronic Media. Singapore: Mcgrawhill Book \& Co. 